UNTAG Law Review (ULREV)

Volume 4, Issue 1, May 2020, PP 71 - 80

ISSN 2549-4910 (online) \& ISSN 2579-5279 (print)

http://jurnal.untagsmg.ac.id/indeks.php/ulrev/indeks

www.fakhukum.untagsmg.ac.id

\title{
PRINCIPLE OF EQUALITY BEFORE THE LAW AND DIVERSION ON CRIMINAL JUSTICE SYSTEM FOR CHILDREN IN INDONESIA
}

\author{
Bambang Joyo Supeno \\ Associate Professor, Faculty of Law, Universitas 17 Agustus 1945 Semarang \\ Email: bambangjoyosupeno@ymail.com
}

\begin{abstract}
Restorative justice is the ultimate goal of Law Number 11 of 2012 concerning the Criminal Justice System for Children, so that children in conflict with the law must obtain Diversion. Article 7 paragraph (2) and Article 9 paragraph (2) the SPPA Law is discriminatory and unjust, both for perpetrators and victims of criminal acts, because there are restrictions, exceptions and disregard for Diversion provisions. In concretto, in 20142018 the use of Diversion (49.61\%) was lower than formal justice $(50.39 \%)$, the data showed that some children who were in conflict with the law did not get Diversion. Based on the analysis of concept the principle of equality before the law in ideal-norm thinking, it is necessary to reconstruct the provisions of Diversion in the SPPA Law, namely (a) The principle of equality before the law must be used as a determining indicator in the formulation and process of Diversion law enforcement. (b) Provisions on child-oriented Diversion as the subject of criminal acts will determine justice in the application of Diversion for every child in conflict with the law. (c) Diversion provisions which are oriented towards acts, sanctions and value of losses as a requirement for the application of Diversion, will cause discrimination in the application of Diversion.
\end{abstract}

Keywords: Criminal Justice System for Children; Diversion; Equality Before The Law

\section{INTRODUCTION}

The crystallization of ideological, moral, religious and social values that are politically constructed in the development of legal substance, legal structure and legal culture encourages the need to pay close attention to the development of the law. In legal development, predictive thinking based on engineering logic will dominate, and there is a tendency to ignore ideal norm thinking which is based on the norms of justice, equality and balance, without any exception (pure thought). In predictive thinking, Oliver Wendell Holmes describes the prediction of rational probabilities of what the court will do when acting as a legislator is as impossible as predicting what rational probabilities will be passed by the legislature. ${ }^{1}$ The meaning of predictive thinking is based on engineering logic that will produce all-round possibilities or uncertainties. Article 1, Article 2 and Article 7 of the Universal Declaration of Human Rights states, that all human beings are born free and equal in dignity and rights and are equal before the law without any discrimination, that is ideal-norm thinking (pure thought). These human rights are the key to protecting human beings from all discriminatory treatments, as regulated in Article 28I paragraph (2) of the 1945 Constitution of the Republic of Indonesia. But in reality, in abstracto, in the perspective of ideal-norm thinking,Article 7 paragraph (2) of Law 1 Jimly Asshiddiqie dan M Ali Safa'at, 2012, Teori Hans Kelsen Tentang Hukum, Jakarta, Konstitusi Press, p.
135-136 
Number 11 Year 2012 concerning the Criminal Justice System for Children (SPPA Law) has governed the provisions of the diversion that contain discriminatory values of the treatment of children as perpetrators of crime, namely limiting Diversion based on the threat of imprisonment under 7 (seven) ) year and repetition of criminal acts, as well as Article 9 paragraph (2) which contains discriminatory value of the treatment of children as victims of criminal acts, which provides an exception must obtain the consent of victims and / or families of children of victims and the willingness of children and their families to commit criminal acts in the form of violations, minor crimes, crime without victims, or value casualty losses are not more than the value of the provincial minimum wage. The formulation of the articles in the SPPA Law does not synergize with the philosophical values in the dictum considering the SPPA Law, that children are the mandate and gift of God Almighty who have dignity and dignity as whole human beings, and sosological values, that children are entitled to special protection, especially legal protection in the criminal justice system. In concretto, based on data analysis of Assistance Results for Children in Conflict with Law in 2014-2018 by the Indonesian Ministry of Women's Empowerment and Child Protection, sourced from the Directorate General of Corrections of the Ministry of Law and Human Rights shows that the application of Diversion $(49.61 \%)$ is lower than the Court's Decision $(50.39 \%)$ in the juvenile criminal justice process. ${ }^{2}$ The data shows that some children as criminals get discriminatory treatment in juvenile criminal justice in Indonesia. This gap needs to be dissected using the knife analysis of the principle of Equality Before the Law in the perspective of ideal-norm thinking in the juvenile justice system law in Indonesia. The analysis is expected to result in the reconstruction of the concept of Diversion in the SPPA Law based on the principle of equality before the law.

\section{PRINCIPLE OF EQUALITY BEFORE THE LAW}

Equality before the law is the principle or basic value of equality of treatment in abstracto (formulation of regulations) and in concretto (law enforcement) in realizing justice. Inequality in the formulation, treatment or imbalance or injustice is the impact of the use of predictive thinking (engineering thinking), and ignores ideal-norm thinking (pure thinking) which prioritizes justice which contains the value of equality and balance, without any exception. In terminology according to the Black's Law Dictionary, Equality before the law is the status or condition of being treated fairly according to regularly established norms of justice. The key word of this definition lies in the word justice as the norm, meaning that in the formulation and enforcement of the law it must be fair, so that if there is discrimination in the formulation and enforcement of the law, it violates the principle or value of equality before the law.

Justice that is born from the principle of equality before the law, is not constitutional justice (distribution) and distributive justice (giving), but fairness of values. In ideal-norm thinking, that the formulation of a just law is a formulation based on the values that exist in the formulation of the law (in abstracto) and carried out in law enforcement (in concretto), and not based on pragmatism (certain interests) with its limitations. For example, the SPPA Act in Indonesia should be based on the value and dignity of the child as the mandate of God Almighty, so that the legal protection is the same for all children, without restrictions and or exceptions based on the threat of criminal sanctions and categories of criminal acts.But in reality, the SPPA Law contains discrimination, both against perpetrators and victims of criminal acts. Article 7 Universal Declaration of Human Rights, Article 26 International

2 Kementerian Pemberdayaan Perempuan dan PerlindunganAnak dan Badan Pusat Statistik, 2016-2019, Profil Anak Indonesia 
Covenant on Civil and Political Rights (ratification of Law Number 12 Year 2005), and Article 28D paragraph (1) of the 1945 Constitution of the Republic of Indonesia regulates the principle of equality before the law which contains equality in law, legal protection and nondiscriminatory treatment before the law. The principle of equality before the law in the SPPA Law is a component of non-discrimination legal protection and the best interests of children in harmony with Article 2 of the Law of the Republic of Indonesia Number 23 of 2002 concerning Child Protection. As stated B. Gronowska, ${ }^{3}$ that equality means equal rights, equality before the law (including equality of legal protection) and equal treatment by public authorities.

The benefit of the principle of Equality before the law embodies justice that is integral to human rights, in line with the opinion of Felipe Probst Werner, that Developed along the years, the access to justice nowadays is consider an integral category of the Human Rights. Integral justice is justice that considers all components involved in realizing justice based on human rights in the formulation of law and law enforcement.

In the Pancasila perspective, the principle of equality before the law is in harmony with the principles of fair and civilized humanity, which means that everything related to humans is

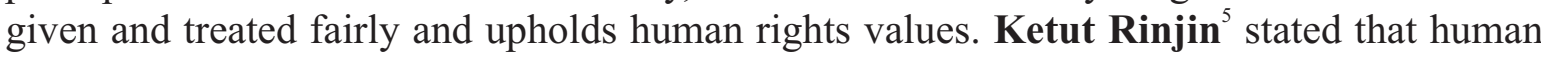
values are fair and civilized, namely 1) love for fellow humans in accordance with the principle that humanity is one, 2) honesty, 3) human safety, 4) justice, and 5) civilization. As stated Mieczyslaw Handzel ${ }^{6}$, that The principle of equality should be somewhat considered in conjunction with the principle of justice.

The principle of equality before the law in Diversion is oriented towards children as subjects of criminal offenses, it should be the same arrangement, both substantively (formulation of law) and process (law enforcement), so that it will give birth to the enforcement of Diversion provisions for all children in conflict with the law. In contrast to the provisions of Diversion which are oriented towards categories of acts (criminal acts), sanctions and the value of losses as a limitation or requirement for the application of Diversion, the enforcement of Diversion provisions will be discriminatory. Make it, the provisions of Diversion which are oriented towards actions, sanctions and the value of losses as a material consideration in Diversion deliberations, so that Diversion decisions will be obtained based on restorative justice.

\section{DIVERSI: AJUSTICE REALITY}

Etymologically, the Black's Law Dictionary provides a definition of Diversion as a deviation or alteration from the natural course of things. In this definition it is still general, with the keywords deviation (alteration) and alteration (change), which can be combined with the word "transfer". In juridical manner, Article 1 number 7 of the SPPA Law, formulates Diversion as an effort to divert the settlement of a Child case from the criminal justice process to the process outside of criminal justice. Diversion is an exceptional effort in the juvenile criminal justice system or a discretionary effort given by the law to Investigators, Public Prosecutors and Judges in the juvenile criminal justice process. Exclusive efforts or discretionary efforts in the

3 Mieczysław Handzel, 2017,The Principle Of Equality Before The Law And Real Property Sales Liable To Personal Income Tax, Scientific Journal WSFiP Nr 1/2017, p. 148

4 Felipe Probst Werner. A Critical View of the Access to Justice in Brazil. International Journal of Law and Society. Special Issue: Access toJustice, Law and Development.Vol. 3, No. 1, 2020, pp.1-4

5 Dodo, Surono, Endah, editor, 2010, Konsistensi Nilai-Nilai Pancasila dalam UUD 1945 dan Implementasinya, Yogjakarta: PSP Press, halaman 80

6 Op.Cit., Mieczysław Handzel, p. 149 
juvenile justice system show the "semi" nature of the juvenile criminal justice process used, meaning that there are 2 (two) types of judicial processes in the juvenile criminal justice system, namely the rational (systemic, judicial process with stages of investigation, investigation, pre-prosecution, trial and coaching) and diversion (atomistic), with each rational stage which can be stopped if there is agreement on the basis of laws and regulations. The problem in abstracto in the juvenile criminal justice system, is not the presence of 2 (two) types of judicial processes, but problems related to the lack of consistency of the SPPA Law and discrimination on equal treatment before the law (equality before the law). The inconsistency of substance related to Diversion in the SPPA Law on the aspects of perpetrators and victims, namely first, Diversion efforts are mandatory efforts (vide Article 5 paragraph (3), Article 7 paragraph (1) of the SPPA Law), but Diversion efforts are not applied to all children as the perpetrators of criminal acts, there are requirements for implementing Diversion in the form of threats of criminal sanctions under 7 (seven) years and not repetition of criminal acts, as regulated in Article 7 paragraph (2) of the SPPA Law. The Diversion judicial process is based on the threat of criminal sanctions and criminal offenses, which should be based on the dignity and rights of children as subjects of criminal acts. The existence of discriminatory requirements in the SPPA Law is contrary to the child protection law. Philosophically, the Preamble to the Convention on the Rights of the Child (ratification of Presidential Decree Number 36 of 1990) reminds that "recognition of the inherent dignity, and equal and inseparable rights of all members of humanity is the basis of freedom, justice and peace in the world "and" the child, for reasons of physical and mental immaturity, needs special protection and care, including proper legal protection, both before and after birth. "Even Article 3 paragraph (1) of the Convention on the Rights of the Child states that "the best interests of the child must be a primary consideration in a court of law," because the child is the trust and gift of God Almighty, which is inherently inherent in the dignity and dignity of God. as a whole person (vide dictum considering Law Number 23 Year 2002). Second, the neglect of the consent of the victim and / or the victim's child and the willingness of the child and his family, for criminal acts in the form of violations, minor crimes, crime without victims and the value of the victim's loss not more than the minimum wage value of the local province. Such neglect constitutes a deviation from the principle of Diversion based on restorative justice, meaning that the resolution of criminal acts is based on agreement in a deliberation between the victim, perpetrator, family, investigator, public prosecutor, judge and Penitentiary as well as other parties in realizing the recovery of conditions such as the beginning, before occurrence of a crime. This waiver is not in line with the 1985 United Nations Standard Rules for the Administration of Juvenile Justice ("The Beijing Rules"), Article 1.1. which states, that any Diversion that involves a referral to an appropriate community or other service must seek the consent of the child, or the parent or guardian. The inconsistency of the substance of the SPPA Law, has an in-concretto effect, that the implementation of Diversion in the juvenile criminal justice process in Indonesia does not apply the principle of equality before the law, resulting in discriminatory treatment and injustice, as Table 1 on Outcomes of Assistance to Children in Conflict with the Law. 
Table 1

Outcomes of Assistance to Children in Conflict with Law

Year 2014 - 2018

\begin{tabular}{|c|c|c|c|c|c|c|c|}
\hline \multirow{2}{*}{ NO } & \multirow{2}{*}{ MESSAGE RESULTS } & \multicolumn{5}{|c|}{ YEAR (\%) } & \multirow{2}{*}{$\begin{array}{l}\text { AVERAGE } \\
(\%)\end{array}$} \\
\hline & & 2014 & 2015 & 2016 & 2017 & 2018 & \\
\hline \multirow[t]{3}{*}{1} & Diversion & 52,69 & 55,23 & 40,00 & 47,35 & 52,80 & 49,61 \\
\hline & $\begin{array}{l}\text { a. Diversion of children back to } \\
\text { parents }\end{array}$ & 51,12 & 51,58 & 37,32 & 42,78 & 48,40 & 46,24 \\
\hline & $\begin{array}{l}\text { b. Diverse children to social or } \\
\text { other institutions }\end{array}$ & 1,57 & 3,65 & 2,68 & 4,57 & 4,40 & 3,37 \\
\hline \multirow[t]{3}{*}{2} & Decision of Action & 10,76 & 5,60 & 15,12 & 12,61 & 15,60 & 11,94 \\
\hline & $\begin{array}{l}\text { a. Decision of the child returns } \\
\text { to the parent }\end{array}$ & 8,74 & 3,65 & 8,19 & 5,85 & 8,80 & 7,05 \\
\hline & $\begin{array}{l}\text { b. Decisions are submitted to } \\
\text { the Social Institution or other }\end{array}$ & 2,02 & 1,95 & 6,93 & 6,76 & 6,80 & 4,89 \\
\hline \multirow[t]{3}{*}{3} & Criminal Verdict & 36,55 & 39,17 & 44,88 & 40,04 & 31,60 & 38,45 \\
\hline & a.Conditional Criminal Verdict & 6,50 & 3,16 & 13,23 & 8,41 & 4,40 & 7,14 \\
\hline & b.Pris on Criminal Verdict & 30,04 & 36,01 & 31,65 & 31,63 & 27,20 & 31,31 \\
\hline \multicolumn{2}{|c|}{ AMOUNT } & 100 & 100 & 100 & 100 & 100 & \\
\hline
\end{tabular}

Based on the data above shows, that the main interests of the dignity of children as the mandate of God Almighty do not get a complete place in the juvenile justice system in Indonesia, is proven discrimination treatment, namely:

a. The application of Diversion is not intended for all children who are in conflict with the law, the data shows the application of Diversi $(49.61 \%)$ and Court Decisions $(50.39 \%)$;

b. Criminal Verdict (38.45\%) is greater than the Verdict of Action (11.94\%);

c. Prison Criminal Verdict (31.31\%) is greater than the Verdict of Action (11.94\%);

The existence of restorative justice aimed at restoring the situation as the ultimate goal of the Diversion should be questioned in the SPPA Law and has failed in the juvenile justice process, because in the criminal justice process the juvenile justice apparatus prefers formal justice to the decision of actions and criminal acts as retaliation (retiributive theory). Yutirsa Yunus ${ }^{7}$ said that the restorative justice paradigm emphasizes restoration to its original state or normal conditions, while the retributive justice paradigm resolves conflicts by punishing perpetrators as a form of retaliation. Restorative justice must be realized in the juvenile criminal justice system in Indonesia and must be diversified, as Article 5 paragraphs (1) and (2) of the SPPA Law, but in the formulation and implementation of Diversion containing discrimination and injustice, the SPPA Law fails to realize restorative justice.

\section{REFORM DIVERSI: EQUALITY BEFORE THE LAW PERSPECTIVE}

Diversion in substance (norms) in the SPPA Law and empirically in law enforcement does not apply the principle of equality before the law as a whole, giving rise to discrimination and injustice for children as perpetrators and victims of criminal acts. The principle of equality before the law emphasizes the value of equality, equality, justice and human rights values in the formulation and implementation of legal

7 Yutirsa Yunus, 2013, Analisis Konsep Restorative Justice Melalui Sistem Diversi Dalam Sistem Peradilan Pidana Anak di Indonesia, Jurnal Rechts Vinding, ISSN-2089 9009, Volume 2, Nomor 2, halaman 235 
norms. The provisions of the SPPA Law relating to Diversion, which deviates from the principle of equality before the law, namely:

a. Provisions for waiver, exclusion, restriction and differences in the formulation and treatment in a norm;

b. Provisions on the entry into force of Diversity which require limits on criminal threats;

c. Provisions requiring a category of criminal offenses;

d. Provisions on the entry into force of the Diversity which require that there is no need for the consent of the victim for criminal acts in the form of violations, minor criminal offenses, criminal offenses without victims and the value of victims' losses not exceeding the minimum wage value of the local province;

The situation has an impact on the realization of restorative justice, so the failure of Article 5 paragraph (1) of the SPPA Law which states that the Child Criminal Justice System must prioritize the Restorative Justice approach. Likewise, the SPPA Act failed to realize formal justice can only be done as a last resort, as Article 16 of Law Number 23 of 2002 concerning Child Protection. If the purpose of restorative justice to restore the original condition is not achieved, then the Diversion objective in Article 6 of the SPPA Law is not achieved, namely:

a. achieving peace between victims and children;

b. settle the Children case outside the judicial process;

c. prevent children from deprivation of independence;

d. encourage the community to participate; and

e. instill a sense of responsibility to the child.

Therefore, it is necessary to renew the substance of Diversion in the SPPA Law from the perspective of equality before the law. Speaking of Diversion from a legal aspect, there are 3 (three) views of the adoption of Diversion, namely:

a. Application of Diversion to all children in conflict with the law without any restriction;

There are 3 (three) arguments that can be used to strengthen the reasons for applying Diversion to all children who are in conflict with the law without any limitation, namely (a) philosophical argumentation, that children are the mandate of God Almighty, who has the right to welfare and legal protection. (b) Legal arguments, that the Universal Declaration of Human Rights, the Convention on the Rights of the Child, the Indonesian Constitution and statutory regulations formulate equality before the law, which is non-discriminatory, and just. (c) Sociological argument, that the adoption of Diversion as an effort to restore the situation as before, eliminating the evil stigma and for the sake of the future interests of children, because children are basically not "evil." Even the United Nations Standard Minimum Rules for the Administration of Juvenile Justice ("The Beijing Rules") 1985, Article 4 paragraph (1) states, that criminal liability of children should not be set at an age level that is too low, keeping in mind the facts of maturity emotional, mental, and intellectual. On the other hand, the state and government guarantee the protection, care and welfare of children by taking into account the rights and obligations of parents, guardians, or other people who are legally responsible for children, as Article 23 paragraph (1) of the Child Protection Act. The application of Diversion which bases these three arguments reflects the principle of equality before the law, so that it will give birth to restorative justice.

b. Application of Diversion to children in conflict with the law, with a limitation

The view of applying Diversion to children in conflict with the law with a limitation is used by the SPPA Act, as stated in Article 7 paragraph (2) of the SPPA Act which regulates the limitation of the application of Diversi based on the threat of criminal sanctions under 7 
(seven) years and the category is not a repeat of criminal acts. Criminal acts that are threatened with criminal sanctions of more than 7 (seven) years or repetition of criminal acts, the child in conflict with the law will undergo a judicial process in the Court. Provisions that carry out restrictions are discriminatory and unjust, so that they neglect the principle of equality before the law, and will give birth to retributive justice.

c. Application of Diversion to children in conflict with the law, with an exception

This view is also adopted in the SPPA Law, in Article 9 paragraph (2) of the SPPA Act, it is stated that the Diversion agreement must obtain the consent of the victim and / or the victim's child and the willingness of the child and his family, except for (a) criminal acts in the form of violations; (b) minor criminal offenses; (c) a crime without a victim; or (d) the value of the loss of the victim is not more than the value of the local provincial minimum wage. The provisions of the Diversion still show the conditions for the exclusion of the Diversion. In ideal norm thinking (pure thinking), the process of deliberation in Diversion should still be based on the agreement of the victim and / or his family, and can be carried out by investigators together with the perpetrators and / or their families, Community Guides, and can involve community leaders, and without requiring action categories criminal and victim losses. If there are exceptions to the conditions, then the provisions do not reflect the principle of equality before the law and will give birth to constitutional justice (distribution).

Diversion in the juvenile criminal justice system in Indonesia needs to be renewed by adhering to the principle of equality before the law, so that the objectives of Diversion and the realization of restorative justice can be realized, so that the consistency of the substance of the SPPAAct will be described. The concept of Diversion renewal in the SPPA Law prioritizes the interests of children based on norm ideal thinking (pure thinking), so that children who are in conflict with the law will get Diversion, without restrictions, neglect and exceptions. The concept of

Table 2

The Concept of Diversity Renewal In the Child Criminal Justice System in Indonesia Equality Perspective Before The Law

\begin{tabular}{|c|c|c|}
\hline \multirow{2}{*}{ NO } & \multicolumn{2}{|c|}{ REFO RM } \\
\hline & SPPA LAW & CONCEPT \\
\hline 1 & $\begin{array}{l}\text { Article } 7 \text { paragraph (2) } \\
\text { Diversity as referred to in paragraph } \\
\text { (1) shall be carried out in the event } \\
\text { that a criminal offense is committed: } \\
\text { a. threatened with im prisonment of } \\
\text { under } 7 \text { (seven) years; and } \\
\text { b. is not a repeat of a crim inal offense. }\end{array}$ & $\begin{array}{l}\text { Article } 7 \text { paragraph }(2) \\
\text { Diversion as referred to in paragraph } \\
\text { (1) is implem ented for all children in } \\
\text { conflict with the law, without any } \\
\text { exceptions. }\end{array}$ \\
\hline 2 & $\begin{array}{l}\text { Article } 9 \text { paragraph (1) } \\
\text { In vestigators, Public Prosecutors, and } \\
\text { Judges in conducting Diversion must } \\
\text { consider: } \\
\text { a. criminal category; } \\
\text { b. age of the child; } \\
\text { c. social research results from Bapas; } \\
\text { and } \\
\text { d. family and community environm ent } \\
\text { support. }\end{array}$ & $\begin{array}{l}\text { Article } 9 \text { paragraph (1) } \\
\text { Investigators, Public Prosecutors, } \\
\text { and Judges in conducting Diversion } \\
\text { must consider: } \\
\text { a. age of the child; } \\
\text { b. social research results from Bapas; } \\
\text { and } \\
\text { a. c. fam ily and community } \\
\text { environment support. }\end{array}$ \\
\hline
\end{tabular}




\begin{tabular}{|c|c|c|}
\hline 3 & $\begin{array}{l}\text { Article } 9 \text { paragraph (2) } \\
\text { Diversion Agreement must obtain the } \\
\text { consent of the victim and / or the } \\
\text { victim's child and the will ingness of } \\
\text { the child and his family, except for: } \\
\text { a. criminal acts in the form of } \\
\text { violations; } \\
\text { b. minor criminal offenses; } \\
\text { c. crime without victims; or } \\
\text { d. the loss value of the victim is not } \\
\text { more than the value of the local } \\
\text { provincial minimum wage. }\end{array}$ & $\begin{array}{l}\text { Article } 9 \text { paragraph (2) } \\
\text { The agreement resulting from the } \\
\text { Diversion deliberation must obtain } \\
\text { the consent of the victim and / or the } \\
\text { victim's child and the willingness of } \\
\text { the child and his family }\end{array}$ \\
\hline 4 & $\begin{array}{l}\text { Article } 10 \text { paragraph (1) } \\
\text { Diversion Agreement to settle } \\
\text { criminal offenses in the form of } \\
\text { violations, minor crimes, criminal } \\
\text { offenses without victims, or the value } \\
\text { of the loss of the victim is not more } \\
\text { than the minimum wage value of the } \\
\text { local province as referred to in Article } \\
9 \text { paragraph (2) can be carried out by } \\
\text { the investigator along with the } \\
\text { offender and / or his family, } \\
\text { Community Guidance, and can } \\
\text { involve community leaders. }\end{array}$ & $\begin{array}{l}\text { Article } 10 \text { paragraph (1) } \\
\text { Agreement on the results of the } \\
\text { Diversity Consultation, as referred to } \\
\text { in Article } 9 \text { paragraph (2) can be } \\
\text { carried out by the investigator } \\
\text { together with the perpetrator and / or } \\
\text { his family, the Community } \\
\text { Guidance, and can involve } \\
\text { community leaders. }\end{array}$ \\
\hline
\end{tabular}

Based on Table 2 shows, that the renewal of the concept of Diversion from the perspective of equality before the law includes 2 (two) aspects, namely:

a. Application of Diversion

Diversion of all children in conflict with the law, without regard to the threat of criminal sanctions, categories of criminal acts, the value of losses of criminal acts, and not based on the consent of the victims, perpetrators, victims' families and perpetrators, correctional centers, social institutions and law enforcement, as The concept of Article 7 paragraph (2) of the SPPA Law. Enforcement of Diversion in the Concept of the Renewal of the SPPA Law is an enforcement of an order of the law (norm), not by order or agreement of the parties involved in the Diversion. The philosophical, legal and sociological arguments above reinforce the interests of the child that takes precedence in the application of Diversion to all children in conflict with the law, without any exceptions.

b. Approval of the results of the Diversion deliberation

The success of Diversion's results in its implementation (empirical) is influenced by the agreement or agreement of the parties in the Diversion deliberations by basing on a constructive positive assessment of the parties. The constructive positive assessment is in the form of views on children in conflict with the law, including among others (a) children are the mandate of God Almighty; (b) children have dignity and that must be protected; (c) basically children are not evil; (e) The State, Government, Society, Family and Parents have obligations and responsibilities towards the welfare and protection of children; (f) avoid stigmatization or evil labeling of children; $(\mathrm{g})$ building a next generation of quality. In 
realizing restorative justice, the results of the Diversion deliberation, among other things, must result in a cumulative positive-action decision verdict in the form of:

a. social rehabilitation, foster awareness of the knowledge, understanding and understanding of actors towards the values of shared life in society, such as the value of tolerance, mutual cooperation, mutual respect and respect, entrepreneurial values, and ethical values and social norms;

b. mental rehabilitation, heal the mental illness of the "sick" because of broken home, discrimination, sensitive feelings, violence, lack of family attention by providing motivation or enlightenment about confidence in life and a life that is beneficial to others;

c. social reintegration, returning actors to society through practical and integral actions in an activity with the community

Renewal of the concept of Diversion substantively from the aspects of equality before the law above, which is oriented to the same legal protection of children in conflict with the law, with all the problems that will occur in the Diversion process, will become guidelines for judicial institutions (including the Penitentiary) in implement Diversion provisions that will produce restorative justice. Anja Seibert-Fohr ${ }^{8}$ said Equal protection of the law, as a matter of substantive equality, has raised many difficulties, as the principle of equality itself is intrinsically vague and therefore requires specification.

In contrast to the SPPA Law which normatively ignores, excludes and limits the requirements for implementing Diversion, so that not all children who are in conflict with the law obtain Diversion, and the decision is more retributive, so that it is possible to repeat a criminal act (recidivist). Diversion must be sought in the juvenile criminal justice process, but in reality according to the data in Table 1, most children who are in conflict with the law do not enjoy Diversion. The accountability of judicial institutions that do not implement the "obligatory Diversion" provisions is questionable, whereas Article 7 paragraph (1) of the SPPA Law determines "obligatory Diversion", and Article 96 of the SPPA Law should be applied to Investigators, Public Prosecutors and Judges who deliberately did not carry out their obligations Article 7 paragraph (1) of the SPPA Law with imprisonment or fines.United Nations Standard Minimum Rules for the Administration of Juvenile Justice ("The Beijing Rules") 1985, Pasal 11.2state, that The police, the prosecution or other agencies dealing with juvenile cases shall be empowered to dispose of such cases, at their discretion, without recourse to formal hearings, in accordance with the criteria laid down for that purpose in the respective legal system and also in accordance with the principles contained in these Rules.

Reconstruction of the SPPA Act must be oriented to the formulation of the implementation of Diversion for all children who are in conflict with the law on the orders of law and the results of the Diversion deliberations based on agreement or agreement on the same perception of children in conflict with the law. In the reconstruction of the SPPA Law must also reflect the consistency of the provisions of the articles.

\section{CONCLUSION}

Diversion in the SPPAAct in abstracto and in concretto results in discrimination and injustice, so that substantive reconstruction needs to be carried out in relation to the Diversion provisions from the aspect of Diversity implementation for all children in conflict with the law and

8 Anja Seibert-Fohr, 2010, The Rise of Equality in International Law and Its Pitfalls: Learning from Comparative Constitutional Law, Volume 35, Brooklyn Journal of International Law, p. 22 
approval of the Diversion deliberations from the parties involved in the Diversion deliberation. The principle of equality before the law must be used as a determining indicator in the formulation and process of Diversion law enforcement. Provisions on child-oriented Diversion as the subject of criminal acts will determine justice in the application of Diversion for every child in conflict with the law. The provisions of Diversion which are oriented towards acts, sanctions and the value of losses as a requirement for the implementation of Diversion, will cause discrimination in the application of Diversion, but will result in fairness if the actions, sanctions and value of losses are taken into consideration in the Diversion deliberations which will result in a Restorative justice decision. Restorative justice as the ultimate goal of justice in the SPPA Act will be realized, if the reconstruction of Diversion provisions in the SPPA Law uses the principle of equality before the law from the perspective of ideal-norm thinking (pure thinking).

\section{REFERENCES}

Anja Seibert-Fohr. 2010. The Rise of Equality in International Law and Its Pitfalls: Learning from Comparative Constitutional Law. Volume 35.Brooklyn Journal of International Law

Dodo, Surono,Endah, editor. 2010. Konsistensi Nilai-Nilai Pancasila dalam UUD 1945 dan Implementasinya. Yogjakarta: PSP Press

Felipe Probst Werner. 2020. A Critical View of the Access to Justice in Brazil.Special Issue: Access to Justice, Law and Development. Vol.3, No.1. International Journal of Law and Society.

JimlyAsshiddiqie dan M Ali Safa'at. 2012. Teori Hans KelsenTentangHukum. Konstitusi Press, Jakarta

Mieczysław HANDZEL. 2017.The Principle Of Equality Before The Law And Real Property Sales Liable To Personal Income Tax.No.1. Scientific Journal WSFiP

Yutirsa Yunus. 2013 . AnalisisKonsep Restorative Justice MelaluiSistemDiversiDalamSistemPeradilanPidanaAnak di Indonesia.Volume 2, Nomor 2. JurnalRechtsVinding, ISSN-2089 9009,

Ministry of Women's Empowerment and Child Protection and Central Statistics Agency, 20162019.ProfilAnak Indonesia

The 1945 Constitution of the Republic of Indonesia

Law Number 23 of 2002 concerning Child Protection

Law Number 11 of 2012 concerning the Criminal Justice System for ChildrenUnited Nation Declaration of Human Rights

United Nations Standard Minimum Rules for the Administration of Juvenile Justice 1985

International Covenant on Civil and Political Right, which has been ratified by Indonesia by Law Number 12 of 2005 